\title{
Effects of hypoxia on DNA hydroxymethylase Tet methylcytosine dioxygenase 2 in a KG-1 human acute myeloid leukemia cell line and its mechanism
}

\author{
PING HE $^{1 *}$, JIAN LEI $^{2 *}$, LI-XIN ZOU ${ }^{1}$, GUI-ZHEN ZHOU ${ }^{3}$, LANG PENG ${ }^{1}$, QIAN DENG ${ }^{1}$ and XIAO-LIU LIU ${ }^{1}$ \\ ${ }^{1}$ Department of Hematology, The Affiliated Changsha Hospital, Hunan Normal University, Changsha, Hunan 410006; \\ ${ }^{2}$ Department of Pathology, The Affiliated Tumor Hospital, Xiangya School of Medicine, Central South University, \\ Changsha, Hunan 410013; ${ }^{3}$ Department of Hematology, Changsha Central Hospital, Changsha, Hunan 410018, P.R. China
}

Received October 19, 2020; Accepted June 4, 2021

DOI: $10.3892 / \mathrm{ol} .2021 .12953$

\begin{abstract}
Hypoxia is involved in the epigenetic modification of leukemia. As an important DNA hydroxymethylase and a tumor suppressor gene, the expression regulating mechanism of Tet methylcytosine dioxygenase 2 (TET2) remains unclear. The aim of the present study was to explore whether hypoxia and hypoxia-inducible factor $1 \alpha(\mathrm{HIF}-1 \alpha)$ regulate TET2 gene expression and its demethylation function in acute myeloid leukemia (AML). The human AML cell line KG-1 was used in the present study. The results demonstrated that hypoxia could increase proliferation, enhance metabolism and inhibit apoptosis in KG-1 cells, as detected by the cell counting kit-8 assay, lactate dehydrogenase assay and Annexin V-FITC/propidium iodide staining, respectively. Hypoxia reduced the genome methylation status in $\mathrm{KG}-1$ cells detected using 5-methylcytosine and 5-hydroxymethylcytosine detection kits. In addition, HIF-1 $\alpha$ overexpression increased TET2 expression, 5-hmC level and cyclin-dependent kinase inhibitor 2B [p15(INK4B)] gene demethylation compared with the HIF-1 $\alpha$ non-overexpression group in KG-1 cells detected by reverse transcription-quantitative PCR, western blotting, 5-hydroxymethylcytosine detection kits and methylation-specific PCR, respectively. The inhibition of HIF-1 $\alpha$ by inhibitor YC-1 reduced demethylation in $\mathrm{KG}-1$ cells by decreasing TET 2 expression. It was also revealed that HIF-1 $\alpha$ could enhance TET 2 transcriptional activity by binding to the hypoxia response element of the TET2 gene promoter region using chromatin immunoprecipitation and
\end{abstract}

Correspondence to: Dr Xiao-Liu Liu, Department of Hematology, The Affiliated Changsha Hospital, Hunan Normal University, 70 Lushan Road, Changsha, Hunan 410006, P.R. China E-mail: liuxiaoliu_2008@163.com

*Contributed equally

Key words: hypoxia, hypoxia-inducible factor $1 \alpha$, Tet methylcytosine dioxygenase 2, demethylation, acute myeloid leukemia luciferase reporter gene assays. TET2 may be a potential target gene regulated by HIF-1 $\alpha$. Hypoxia was demonstrated to regulate the expression of TET 2 by HIF- $1 \alpha$, which in turn affected the methylation and expression of downstream target genes and served a role in the occurrence and progression of leukemia. In the present study, the association between hypoxia metabolism and epigenetic regulation in AML was investigated and the findings provided a new idea and experimental basis for the diagnosis and treatment of hematologic malignancies.

\section{Introduction}

Acute myeloid leukemia (AML) results from accumulation of abnormal myeloblasts, most commonly in the bone marrow, leading to bone marrow failure and death (1). Cellular hypoxia in solid tumors, such as kidney cancer and colon cancer (2) is also present in hematologic malignancies, such as AML and lymphoma (3). Although, normal mammalian bone marrow is relatively hypoxic compared with other tissues, such as liver and kidney, hematopoietic stem cells can be found in the lowest-oxygen microenvironment of the bone marrow (4). Leukemic stem cells reside in the most hypoxic areas within the hematopoietic stem/progenitor cells niche $(5,6)$. Under hypoxic conditions, hypoxia-inducible factor $1 \alpha(\mathrm{HIF}-1 \alpha)$ is transferred into the nucleus, via the hypoxia response element (HRE)-specific binding regulating gene expression (7).

HIF-1 $\alpha$ regulates target genes, such as vascular endothelial growth factor, E-cadherin and Bcl-2 involved in several physiological processes, such as erythropoiesis and angiogenesis, and in certain pathological processes, including cancer cell metastasis and cancer stem cell self-renewal (8). It was found that HIF-1 $\alpha$ was upregulated in childhood acute lymphoblastic leukemia bone marrow blasts (9). HIF-1 $\alpha$ expression has been found to be associated with poor survival prognosis in adult acute myeloid leukemia (AML) with normal karyotype (10). However, it has also been demonstrated that HIF-1 $\alpha$ can induce AML cell differentiation and inhibit the progression of AML (11). The role of hypoxia and HIF remains controversial depending on the study and model, and hence requires further research. 
Abnormal regulation of epigenetic modification in hematological malignancy can lead to transcriptional silencing of tumor suppressor genes, such as cyclin-dependent kinase inhibitor 2B [p15(INK4B)] and hypermethylated in cancer 1 (HIC-1) and increase in abnormal clones (12). Previous studies have found that epigenetic modification serves an important role in hypoxia response $(13,14)$. It has been reported that hypoxia causes demethylation of the $\mathrm{CpG}$ island and expression of Wilms' tumor gene (WT1) mRNA in myeloid leukemia cells (15). Whether hypoxia and HIF-1 are involved in other epigenetic modifications requires further research.

As an $\alpha$-ketoglutarate and Fe (II)-dependent oxygenase, Tet methylcytosine dioxygenase 2 (TET2) catalyzes the conversion of 5-methylcytosine (5-mC) to 5-hydroxymethylcytosine (5-hmC), and 5-hmC leads to the demethylation of cytosine (16). The TET2 gene is expressed in various human tissues, such as heart and placenta (17), but the highest expression has been identified in hematopoietic cells (18). Since Delhommeau et al (19) reported the expression of TET2 in myeloid malignancies in 2009 , extensive attention has been paid to the significance of this gene in hematologic malignancies. Recently, it was reported that TET2 also participated in the regulation of the immune system, TET activity is a biomarker for predicting the efficiency of anti-programmed cell death protein 1/programmed cell death ligand 1 therapy in solid tumors (20).

The effect of hypoxia on the methylation of AML cells was observed on 2 levels: Methylation at the genome level and methylation of specific genes (21). The p15 (INK4B) gene was chosen as the specific gene for investigation of methylation in the present study. As a tumor suppressor gene (22), p15(INK4B) can affect the cell proliferation cycle by inhibiting the expression of cyclin-dependent kinase (CDK) 4 and CDK6 (23). In the occurrence and development of various hematologic malignancies, such as myelodysplastic syndrome and AML, p15(INK4B) gene inactivation has been demonstrated to be caused by the abnormal methylation of $\mathrm{CpG}$ islands (24). The mechanism of p15(INK4B) gene methylation remains unclear (25) and p15(INK4B) gene methylation under hypoxia has not been reported.

As an important DNA hydroxymethylase and a tumor suppressor gene, the mechanism of TET2 gene regulation remains unclear (26). Bioinformatics analysis revealed two HREs (5'-caCGTG-3') at -1078-1075 and -12-9 bp of the TET2 gene promoter. Therefore, we hypothesized that HIF-1 $\alpha$ may regulate TET 2 gene expression by binding to its promoter region, hence serving an important role in the epigenetic regulation.

Based on the above hypothesis, the aim of the present study is to observe the changes in genome methylation status under hypoxia in an AML cell line KG-1 and study the effect of hypoxia and HIF-1 $\alpha$ on TET2 gene expression and its function. In addition, the relevant regulatory mechanism will be explored. The association between hypoxic metabolism and epigenetic modification in leukemic cells was revealed by the present study.

\section{Materials and methods}

Cell culture and hypoxia. KG-1, a human AML cell line was provided by Procell Life Science \& Technology Co., Ltd. The cells were cultured in Iscove's modified Dulbecco's medium (Thermo Fisher Scientific, Inc.) supplemented with 20\% FBS (Thermo Fisher Scientific, Inc.) and $1 \%$ penicillin-streptomycin at $37^{\circ} \mathrm{C}$. Normoxic cells were incubated at $21 \% \quad \mathrm{O}_{2}$ and $5 \% \mathrm{CO}_{2}$. Physical hypoxic cells were incubated in the hypoxic incubator (Thermo Fisher Scientific, Inc.), and in an atmosphere of $1 / 3 \% \mathrm{O}_{2}, 92 / 94 \% \mathrm{~N}_{2}$ and $5 \% \mathrm{CO}_{2}$ for 24,48 and $72 \mathrm{~h}$.

Cell Counting Kit (CCK)-8 assay. Proliferation of KG-1 cells was detected using the CCK-8 assay (Dojindo Molecular Technologies, Inc.) according to the manufacturer's instructions. Briefly, the cells were seeded $\left(5 \times 10^{4}\right.$ cells $\left./ \mathrm{ml}\right)$ and incubated at $37^{\circ} \mathrm{C}$ in 96 -well plates for 24,48 and $72 \mathrm{~h}$. A total of $10 \mu \mathrm{l}$ CCK-8 solution was added to the cells and incubated for $2 \mathrm{~h}$ in the dark. Absorbance [optical density (OD) values] was measured at $450 \mathrm{~nm}$ using a microplate reader (Bio-Rad Laboratories, Inc.).

Lactate dehydrogenase ( $L D H)$ assay. Cell cultures were collected $\left(5 \times 10^{4}\right.$ cells $\left./ \mathrm{ml}\right)$ and added to a 96 -well plate using an LDH kit (Nanjing Jiancheng Bioengineering Institute), according to the manufacturer's instructions. After the sample was added and incubated, The absorbance was read at $450 \mathrm{~nm}$ on a microplate reader (Bio-Rad Laboratories Inc.).

Annexin V/propidium iodide (PI) apoptosis detection assay. Both early and late stages of apoptosis were detected using a FITC Annexin V Apoptosis Detection kit (cat. no. 556547; BD Biosciences). Cells were harvested, resuspended in $100 \mu \mathrm{l}$ binding buffer, labeled with $5 \mu \mathrm{l}$ Annexin V-FITC, followed by $5 \mu \mathrm{PI}$ and incubated for $15 \mathrm{~min}$ at room temperature $\left(25^{\circ} \mathrm{C}\right)$ in the dark. Next, $400 \mu \mathrm{l}$ binding buffer was added and cells were then analyzed by flow cytometry within $1 \mathrm{~h}$. Data were analyzed using FlowJo v.7.6.1; FlowJo, LLC following flow cytometry on a FACSCalibur flow cytometer (BD Biosciences).

Global DNA methylation assessment. Genomic DNA was extracted from KG-1 cells using a Genomic DNA kit (cat. no. DP304; Tiangen Biotech Co., Ltd.). The global DNA methylation level was quantified in $100 \mathrm{ng}$ genomic DNA using the MethylFlashTM Methylated DNA Quantification kit (cat. no. P-1034; EpiGentek Group, Inc.), following manufacturer's instructions. Briefly, the methylated DNA was detected using capture and detection antibodies according to the manufacturer's instructions for 5-mC and then quantified calorimetrically by measuring absorbance at $450 \mathrm{~nm}$ using the PowerWave HT Microplate Spectrophotometer (BioTek Instruments, Inc.). The amount of methylated DNA was proportional to the OD intensity measured. Relative quantification was used to calculate the percentage of 5-mC in total DNA as described by the manufacturer's instructions. Each sample was run in duplicate.

5-hmC level assay. 5-hmC levels of genomic DNA were quantified using the MethylFlash ${ }^{\mathrm{TM}}$ Hydroxymethylated DNA Quantification kit (cat. no. P-1036; EpiGentek Group, Inc.). According to the manufacturer's instructions, the hydroxymethylated fraction of DNA was detected through the capture and detection of antibodies, followed by colorimetric quantification. To quantify the absolute amount of hydroxymethylated 
DNA, first, a standard curve was generated between OD values and the amount of positive control at each concentration point, the slope of the standard curve was determined using linear regression, and then the amount of 5-hmC in the total DNA was calculated using the following formula: $5-\mathrm{hmC} \%=($ Sample OD-Negative control OD)/(SlopexInput DNA amount) x100\%. Each sample was run in duplicate.

Reverse transcription-quantitative $(R T-q) P C R$. Total RNA was extracted using TRIzol ${ }^{\circledR}$ reagent (Thermo Fisher Scientific, Inc.). An equal amount $(3 \mu \mathrm{g})$ of total RNA was used for cDNA synthesis with the MMLV Reverse Transcription kit (Thermo Fisher Scientific, Inc.), according to the manufacturer's instructions. The cDNA was amplified and quantified using a SYBR Green qPCR kit (cat. no. 330521; Thermo Fisher Scientific, Inc.). The thermocycling conditions used for RT-qPCR were as follows: Thermal denaturation for $5 \mathrm{~min}$ at $95^{\circ} \mathrm{C}$; amplification for $30 \mathrm{sec}$ at $95^{\circ} \mathrm{C}, 60^{\circ} \mathrm{C}$ for $30 \mathrm{sec}$ for 40 cycles; and final extension at $72^{\circ} \mathrm{C}$ for $10 \mathrm{~min}$. After all PCR reactions are completed, the temperature was maintained at $4^{\circ} \mathrm{C}$. The following primer sequences were used for RT-qPCR: HIF-1 $\alpha$ forward, 5'-TCTCAGAATGAAGTG TACCCTAA-3' and reverse, 5'-TCACAAATCAGCACCAAG C-3'; TET2 forward, 5'-CCCACAGAGACTTGCACAACA T-3' and reverse, 5'-CTGGCTCTGCTAACATCCTGAC-3'; and $\beta$-actin forward, 5'-TTCCAGCCTTCCTTCCTGGG-3' and reverse, 5'-TTGCGCTCAGGAGGAGCAAT-3'. To test the specificity of the PCR reaction, products were subjected to melting curve analysis and conventional $2 \%$ agarose gel electrophoresis to rule out the synthesis of unspecific products. All quantitative assays were performed in duplicate. Values obtained for the target gene expression were normalized to $\beta$-actin and calculated using the $2^{-\Delta \Delta \mathrm{Cq}}$ method (27).

Western blotting. KG-1 cells were collected and lysed using RIPA lysis buffer (Thermo Fisher Scientific, Inc.) containing protease and phosphatase inhibitors (Roche Applied Science). The supernatants were collected via centrifugation at $12,000 \mathrm{x} \mathrm{g}$ for $15 \mathrm{~min}$ at $4^{\circ} \mathrm{C}$. Total protein was quantified using the bicinchoninic acid (BCA) protein assay kit (Beyotime Institute of Biotechnology). Proteins were resolved using $10 \%$ SDS PAGE, transferred onto PVDF membranes (mass of protein loaded was $20 \mu \mathrm{g} / \mathrm{lane}$ ) and blocked with $5 \%$ skimmed milk for $1.5 \mathrm{~h}$ at room temperature. The membranes were incubated with primary antibodies (all 1:1,000), mouse-anti-HIF-1 $\alpha$ monoclonal antibody (cat. no. H1alpha67; Abcam), rabbit-anti-TET2 polyclonal antibody (cat. no. ab94580; Abcam) or rabbit-anti- $\beta$-actin monoclonal antibody (cat. no. 4967; Cell Signaling Technology, Inc.) respectively, overnight at $4^{\circ} \mathrm{C}$. Following the primary incubation, membranes were incubated with secondary antibodies (1:20,000; cat. no. 926-32211; LI-COR Biosciences) for $1 \mathrm{~h}$ at room temperature. The membranes were visualized using an enhanced chemiluminescence kit (EMD Millipore). Semi-quantitative analysis was performed using ImageJv.1.8.0 software (National Institutes of Health).

Transfection with lentivirus-HIF-1 $\alpha$-overexpression. Lentiviral vectors encoding HIF-1 $\alpha$ overexpression were generated using the GV358 vector (Shanghai GeneChem
Co., Ltd.) and designated as GV358-HIF-1 $\alpha$. The empty vector (GV358) was used as a negative control. Lentiviral infection was conducted following the manufacturer's instructions (2nd generation system). Briefly, Lentiviral vectors (GV358) encoding containing HIF-1 $\alpha$ overexpression (Shanghai GeneChem Co., Ltd.) and empty control were transduced into KG-1 cells (Procell Life Science \& Technology Co., Ltd.). A total of $5 \times 10^{4}$ cells $/ \mathrm{ml}$ cell suspension with complete medium (80\% IMDM media +20\% FBS) was prepared and $2 \mathrm{ml}$ cell suspension/well was inoculated into 6 well plates. Cells were incubated at $37^{\circ} \mathrm{C}$ for $24 \mathrm{~h}$ until they reached $20 \%$ confluence. During transduction, $1 \mathrm{ml}$ of medium was discarded, and $40 \mu \mathrm{l}$ of HiTransG infection solution (Shanghai GeneChem Co., Ltd.) and $40 \mu \mathrm{l}$ of lentivirus solution (MOI was 20 according to the pre infection experiment and the virus titer was $1 \times 10^{8} \mathrm{TU} / \mathrm{ml}$ ) were added and cells were cultured at $37^{\circ} \mathrm{C}$. After $16 \mathrm{~h}$, the medium was replaced with fresh medium. Transduction efficiency was observed via light and fluorescence microscopy (magnification, x100) after $48 \mathrm{~h}$. The successfully transduced cells had green fluorescence as there were GFP labelled in the lentivirus particles. Subsequent experiments were performed $48 \mathrm{~h}$ after lentivirus infection. There were 4 groups in the study: GV358 + normoxia, GV358-HIF-1 $\alpha$ + normoxia, GV358 + hypoxia and GV358-HIF-1 $\alpha$ + hypoxia.

Suppression of HIF-1a expression by 3-(5'-hydroxymethyl-2'-furyl)-1-benzylindazole (YC-1). YC-1 is a potential anticancer agent that suppresses HIF-1 $\alpha$ expression in cancer cells (28). YC-1 (Merck KGaA) was dissolved in dimethyl sulfoxide (DMSO; Merck KGaA). Cells were incubated with YC-1 at a final concentration of $10 \mu \mathrm{mol} / 1$ for $24 \mathrm{~h}$ before the induction of both normoxia and hypoxia. There were 4 groups in the study: DMSO + normoxia, YC-1 + normoxia, DMSO + hypoxia and YC-1 + hypoxia.

Methylation-specific PCR (MSP). Genomic DNA was extracted from cells using a Genomic DNA kit (Tiangen Biotech Co., Ltd.). MSP was performed to evaluate the methylation status of gene promoters as previously described (29). Bisulfite conversion of DNA was performed using the EZ DNA Methylation-Gold kit (cat. no. D5005; Zymo Research Corp.) according to the manufacturer's instructions. The primers used for the p15(INK4B) gene methylation assay were previously described (29). Methylated-specific primers forward, 5'-GCGTTCGTATTTTGCGGTT-3' and reverse, 5'-CGT ACAATAACCGAACGACCGA-3'; unmethylated-specific primers forward, 5'-TGTGATGTGTTTGTATTTTGTGGT T-3' and reverse, 5'-CCATACAATAACCAAACA ACC AA-3'. Reactions were carried out in a total volume of $20 \mu \mathrm{l}$, containing $1 \mu \mathrm{l}$ bisulfite-modified DNA, $2 \mu \mathrm{l}$ 10X PCR buffer, $1.6 \mu \mathrm{ldNTP}$ mixture $(2.5 \mathrm{mM}$ each), $0.5 \mu \mathrm{l}$ forward primer $(20 \mu \mathrm{M}), 0.5 \mu \mathrm{l}$ reverse primer $(20 \mu \mathrm{M}), 0.1 \mu \mathrm{l}$ Taq Hot Start Polymerase (5 U/ $\mu 1$; Tiangen Biotech Co., Ltd.) and $14.3 \mu \mathrm{l}$ distilled (d) $\mathrm{H}_{2} \mathrm{O}$. Reaction mixtures were denatured at $95^{\circ} \mathrm{C}$ for $2 \mathrm{~min}$. Amplification was then performed for 35 cycles $\left(95^{\circ} \mathrm{C}\right.$ for $30 \mathrm{sec}, 60^{\circ} \mathrm{C}$ for $30 \mathrm{sec}$ and $72^{\circ} \mathrm{C}$ for $40 \mathrm{sec}$ ), followed by a final extension at $72^{\circ} \mathrm{C}$ for $5 \mathrm{~min}$. DNA from control subjects was used as a negative control. Results from duplicate experiments were used to determine methylation status. 
Chromatin immunoprecipitation (ChIP)-qPCR assays. ChIP-qPCR assays were performed as previously described (30) and using an EZ-Magna ChIP A/G kit (EMD Millipore) according to the manufacturer's instructions. Briefly, KG-1 cells were cross-linked with $1 \%$ paraformaldehyde at $37^{\circ} \mathrm{C}$ for $10 \mathrm{~min}$ and sonicated at $0^{\circ} \mathrm{C}$ for $60 \mathrm{sec}$. The genomic DNA was digested to an average size of 100-1,000 bp. Solubilized chromatin was immunoprecipitated with antibodies against HIF-1 $\alpha$ (5 $\mu$ g; cat. no. H1alpha67; Abcam) or negative control IgG antibody ( $2 \mu \mathrm{l}$; cat. no. 2729S; Cell Signaling Technology, Inc.) at $4^{\circ} \mathrm{C}$ overnight. Following proteinase $\mathrm{K}$ treatment and crosslink reversal $\left(62^{\circ} \mathrm{C}\right.$ for $2 \mathrm{~h}$ followed by $95^{\circ} \mathrm{C}$ for $\left.10 \mathrm{~min}\right)$, immunoprecipitated DNA underwent phenol-chloroform extraction with ethanol precipitation. Immunoprecipitated DNA was analyzed using RT-qPCR. PCR amplification was conducted using the precipitated DNA fragment as a template and the relevant primers. The primers used were as follows: Normoxia and hypoxia groups were analyzed by PCR using a HRE primer (forward, 5'-GCCTGGCCAATATGGTGAAAC C-3' and reverse, 5'-CGATTCTTCTGCCTCAGCCTC-3'; $111 \mathrm{bp})$. The positive and negative control groups were analyzed by PCR using the GAPDH promoter primer [forward, 5'-TAC TAGCGGTTTTACGGGCG-3' and reverse, 5'-TCGAACAGG AGGAGCAGAGAGCGA-3' (166 bp)]. The experiments were performed in triplicate.

Luciferase reporter assays. GV354-TET2 promoter luciferase reporter and GV219-HIF-1 $\alpha$ overexpression vectors were constructed by GeneChem, Inc. The GV354-TET2 promoter luciferase reporter vector contained $2 \mathrm{~kb} 5$ '-flanking region and $550 \mathrm{bp} 5$ '-untranslated region of the TET2 gene and authenticity was verified by sequencing (data not shown). For the luciferase reporter assay, KG-1 cells were seeded $\left(5 \times 10^{4}\right.$ cells $\left./ \mathrm{ml}\right)$ in a 24 -well plate. Transfections were performed using X-tremeGENE HP DNA Transfection Reagent (Roche Diagnostics). Each transfection experiment contained $500 \mathrm{ng}$ GV354-TET2 promoter luciferase reporter vector/empty vector, a different dose of GV219-HIF-1 $\alpha$ overexpression vector $(0,1$, 2 and $4 \mu \mathrm{g}$ )/empty vector and $20 \mathrm{ng}$ Renilla expression vector (Thermo Fisher Scientific, Inc.). After $48 \mathrm{~h}$ of transfection, cells were harvested and lysed. Then the firefly and Renilla luciferase activities were measured using the Dual-Glo ${ }^{\circledR}$ Luciferase Assay System Protocol (Promega Corporation). The Renilla luciferase activity was set as the internal control.

Statistical analysis. All experiments were repeated 3 times and the data were presented as the mean \pm standard deviation. Statistical analyses were performed using GraphPad Prism 8 (GraphPad Software, Inc.) and SPSS 20.0 statistical software package (IBM Corp.). Comparisons between 2 groups were conducted using the unpaired Student's t-test and comparisons among multiple groups were performed using two-way ANOVA followed by the post hoc Tukey's test. The correlation analysis was performed using Pearson correlation. $\mathrm{P}<0.05$ was considered to indicate a statistically significant difference.

\section{Results}

Hypoxia increases proliferation, enhances metabolism and inhibits apoptosis in KG-1 cells. The acute myeloid cell line
KG-1 cells were treated with different oxygen concentrations (21, 3 and $1 \%$ ) for 24,48 and $72 \mathrm{~h}$ at $37^{\circ} \mathrm{C}$. The proliferation, destruction and apoptosis of KG-1 cells were detected by CCK-8 assay, lactate dehydrogenase assay and Annexin V-FITC/PI staining, respectively. As shown in Fig. 1A, proliferation was significantly increased in KG-1 cells under hypoxic compared with normoxia. With the decrease of oxygen concentration and prolongation of hypoxia, the proliferation activity of $\mathrm{KG}-1$ cells was gradually enhanced (Fig. 1A). The LDH content in the hypoxia cell culture medium was increased compared with the normoxia medium (Fig. 1B). LDH content was increased with the prolonged hypoxia time and the oxygen concentration decreased, suggesting that hypoxia increased the destruction and metabolism of KG-1 cells. The apoptotic rate of KG-1 cells was decreased with the decrease in oxygen concentration, while the duration of hypoxia had little effect on the rate of cell apoptosis (Fig. 1C). In combination, these data suggested that hypoxia could increase the proliferation, enhance the metabolism and inhibit the apoptosis of KG-1 cells.

Hypoxia increases global 5-hmC levels in KG-1 cells. KG-1 cells were treated with different oxygen concentrations $(21,3$ and $1 \%$ ) for 24,48 and $72 \mathrm{~h}$ and then the genomic demethylation and methylation status were detected using 5-hmC and 5-mC detection kits, respectively. The 5-hmC content in the hypoxia group was higher than that in the normoxia group and the 5-mC content in the hypoxia group was lower than that in the normoxia group, suggesting that hypoxia could reduce the methylated status of the genome in KG-1 cells, while hypoxia time under the same oxygen concentration had little effect on the methylated status of the genome (Fig. 2A and B).

Hypoxia increases HIF-1 $\alpha$ and TET2 expression in $K G-1$ cells. KG-1 cells were treated with different oxygen concentrations $(21,3$ and $1 \%$ ) for 24,48 and $72 \mathrm{~h}$, and then the mRNA and protein levels of HIF-1 $\alpha$ and TET2 were investigated by RT-qPCR and western blotting, respectively. It was demonstrated that hypoxia promoted the expression of HIF- $1 \alpha$ and TET2 mRNA in KG-1 cells and the mRNA levels of HIF-1 $\alpha$ and TET2 were the highest in the $1 \% \mathrm{O}_{2}$ $48 \mathrm{~h}$ group (Fig. 3A and B). Simultaneously, under the same hypoxia concentration, with the extension of hypoxia time, the mRNA expression of HIF-1 $\alpha$ and TET2 were increased (Fig. 3A and B). A positive correlation was identified between the HIF-1 $\alpha$ and TET2 mRNA expression levels (Fig. 3C). In concert, hypoxia promoted the protein expression of HIF-1 $\alpha$ and TET2 in KG-1 cells compared with normoxia (Fig. 4A) and the HIF-1 $\alpha$ protein level was positively correlated with the TET2 protein level (Fig. 4B). Overall, the $1 \% \mathrm{O}_{2}$ for $48 \mathrm{~h}$ was selected as the hypoxic condition to be used for subsequent experiments.

HIF-1 $\alpha$ overexpression increases TET2 expression, 5-hmC level and p15(INK4B) gene demethylation in KG-1 cells. Lentiviral transfection of HIF-1 $\alpha$ eukaryotic expression plasmid was used to induce HIF-1 $\alpha$ overexpression in cells. The $1 \% \mathrm{O}_{2}$ for $48 \mathrm{~h}$ was selected for the hypoxic conditions $\left(1 \% \mathrm{O}_{2}, 94 \% \mathrm{~N}_{2}\right.$ and $\left.5 \% \mathrm{CO}_{2}\right)$. There were 4 groups: GV358 + normoxia, GV358-HIF-1 $\alpha$ + normoxia, GV358 + hypoxia and GV358-HIF-1 $\alpha+$ hypoxia. Cell 
A
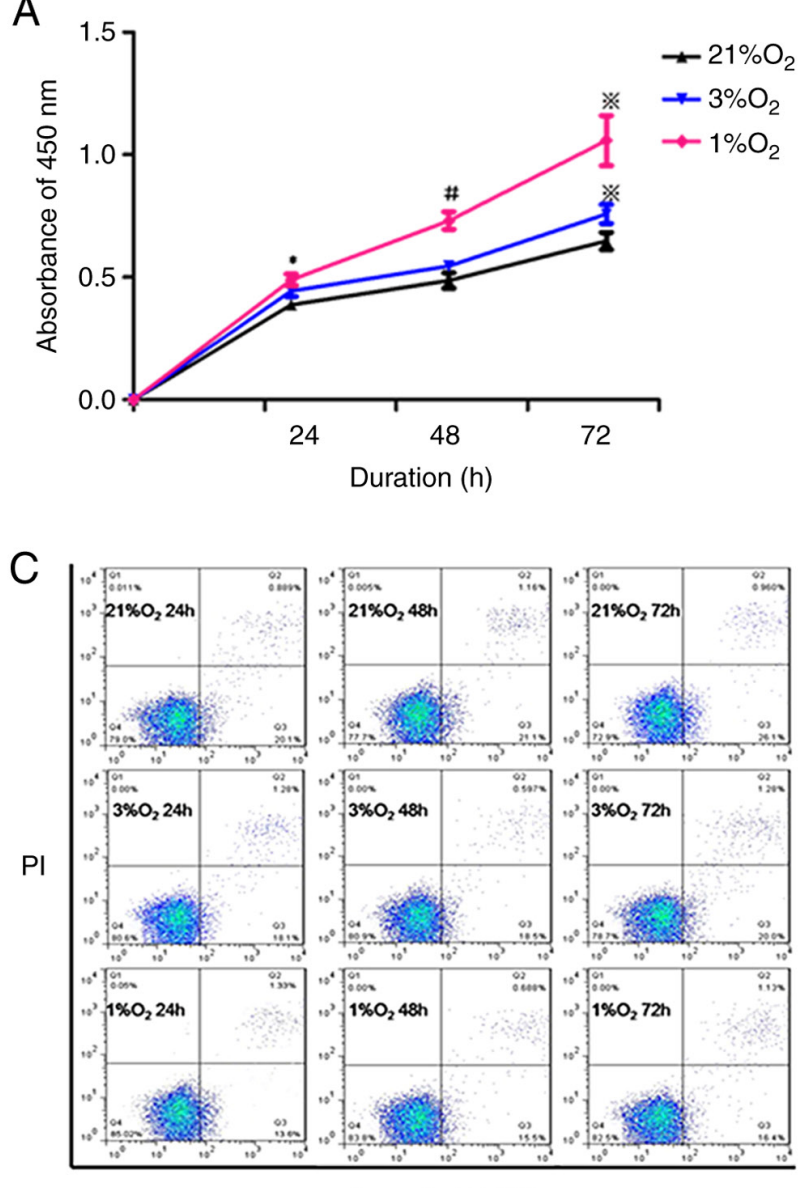

B
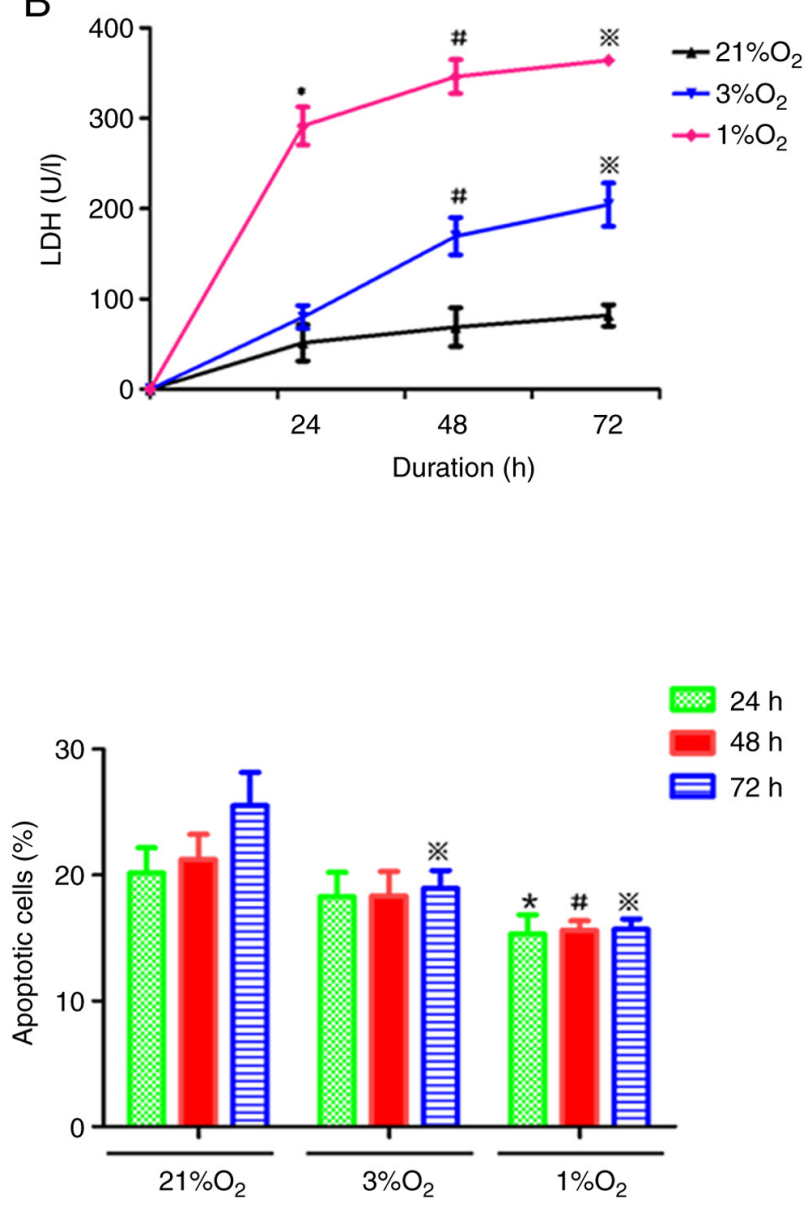

Figure 1. Effects of hypoxia on the proliferative activity of KG-1 cells as detected by (A) Cell Counting Kit- 8 assay. (B) Metabolic activity as detected using a LDH kit. (C) Apoptosis detected using an Annexin V-FITC/PI assay. ${ }^{*} \mathrm{P}<0.05$ vs. $21 \% \mathrm{O}_{2} 24 \mathrm{~h} ;{ }^{*} \mathrm{P}<0.05$ vs. $21 \% \mathrm{O}_{2} 48 \mathrm{~h}$; ${ }^{*} \mathrm{P}<0.05$ vs. $21 \% \mathrm{O}_{2} 72 \mathrm{~h}$. LDH, lactate dehydrogenase; PI, propidium iodide.

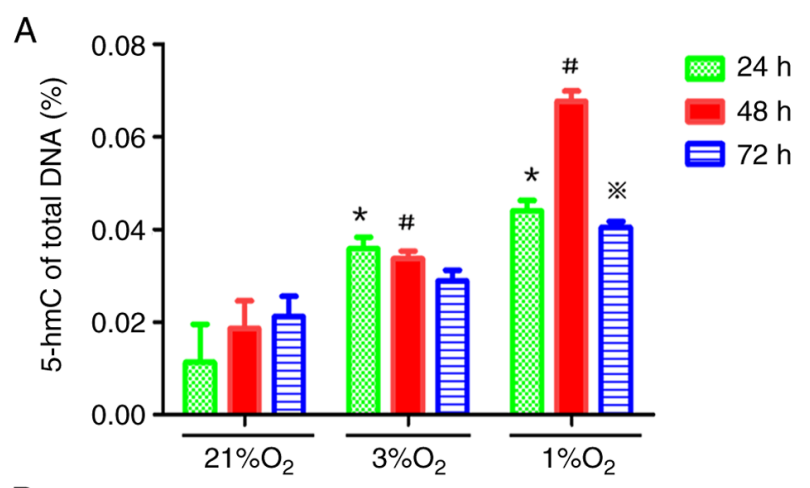

B

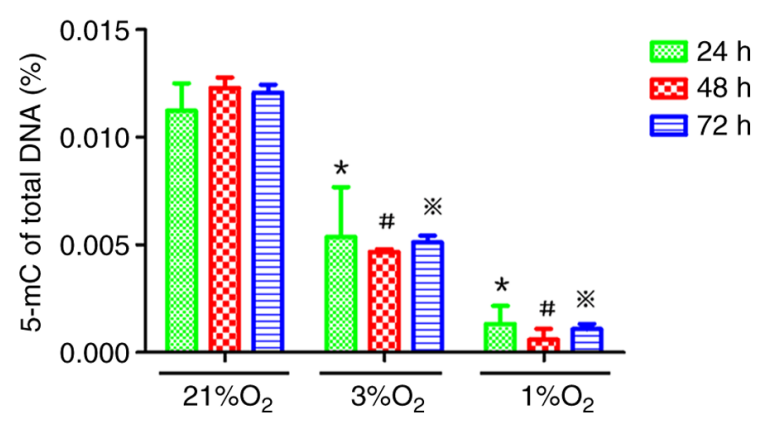

Figure 2. Effects of hypoxia on (A) 5-hmC and (B) 5-mC contents in KG-1 cell genome. ${ }^{*} \mathrm{P}<0.05$ vs. $21 \% \mathrm{O}_{2} 24 \mathrm{~h} ;{ }^{~} \mathrm{P}<0.05$ vs. $21 \% \mathrm{O}_{2} 48 \mathrm{~h} ;{ }^{*} \mathrm{P}<0.05$ vs. $21 \% \mathrm{O}_{2} 72$ h. 5-hmC, 5-hydroxymethylcytosine; 5-mC, 5-methylcytosine. proliferation were increased in the GV358-HIF-1 $\alpha$ + normoxia group compared with the GV358 + normoxia group (Fig. 5A). The proliferation were increased in HIF-1 $\alpha$-overexpressing cells under both normoxia and hypoxic conditions compared with non-HIF-1 $\alpha$-overexpressing cells (Fig. 5A). The apoptotic rate of KG-1 cells was decreased in HIF-1 $\alpha$-overexpressing cells and/or hypoxic conditions compared with non-HIF-1 $\alpha$-overexpressing cells (Fig. 5B and C).

TET2 mRNA and protein levels were increased in the GV358-HIF-1 $\alpha$ + normoxia group compared with the GV358 + normoxia group (Fig. 6A and B). TET2 expression in the GV358-HIF-1 $\alpha+$ hypoxia group was significantly higher compared with in the GV358-HIF-1 $\alpha+$ normoxia group (Fig. 6A and B). Compared with the GV358 + hypoxia group, TET2 expression in KG-1 cells was also increased in the GV358-HIF-1 $\alpha$ + hypoxia group (Fig. 6A and B). Meanwhile, the HIF-1 $\alpha$ mRNA and protein levels were upregulated in HIF- $1 \alpha$-overexpressing cells under both normoxia and hypoxic conditions (Fig. 6A and B). This indicated that the TET2 mRNA and protein levels were upregulated in HIF-1 $\alpha$-overexpressing cells under both normoxia and hypoxic conditions (Fig. 6A and B).

Compared with the GV358 + normoxia group, the content of 5-hmC in the genome of KG-1 cells was increased in the GV358-HIF-1 $\alpha+$ normoxia group (Fig. 6C). The content of 

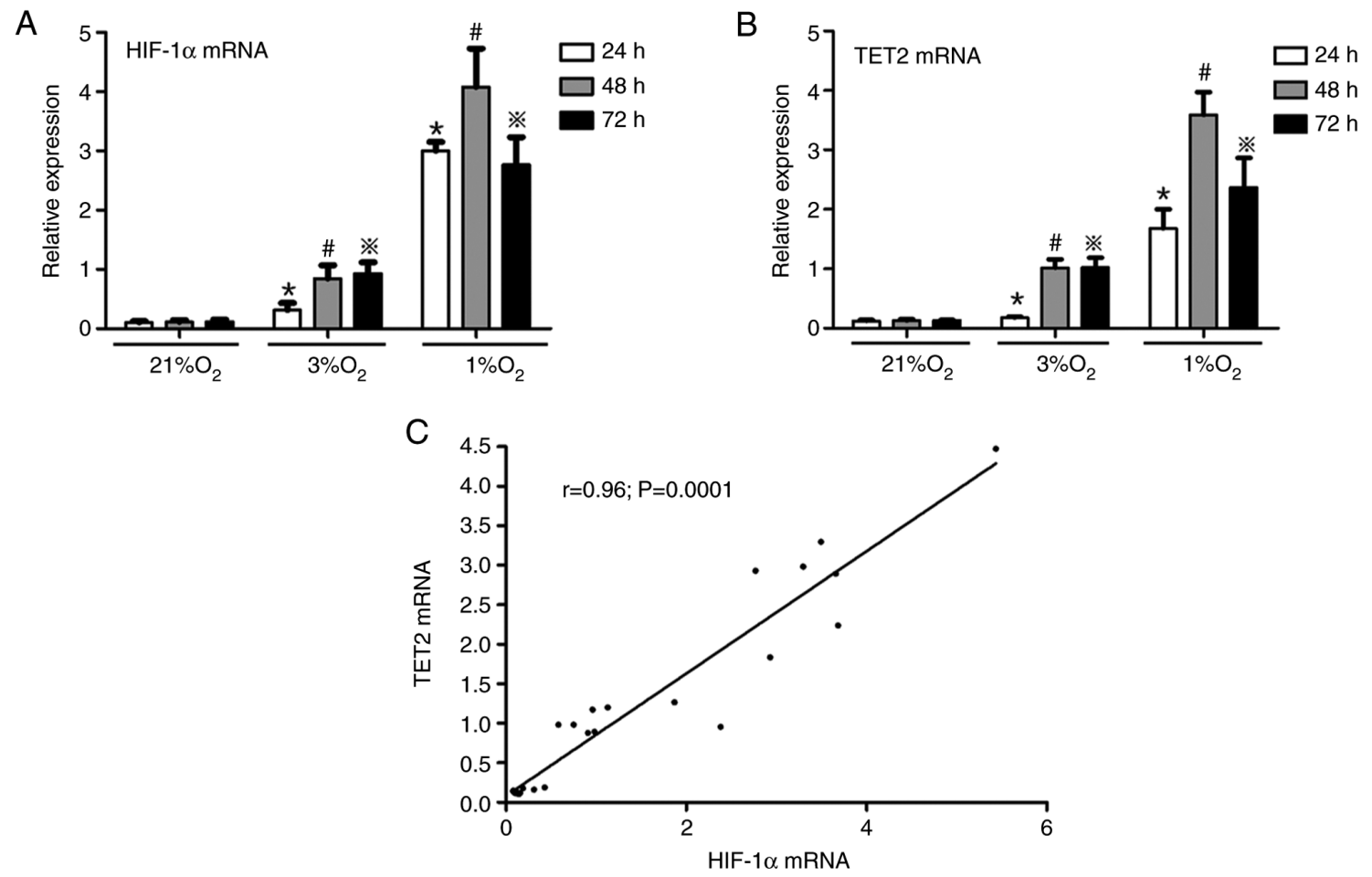

Figure 3. Effects of hypoxia on the expression of (A) HIF-1 $\alpha$ and (B) TET2 mRNA in KG-1 cells and (C) the association between the expression of HIF-1 $\alpha$ and TET2. ${ }^{*} \mathrm{P}<0.05$ vs. $21 \% \mathrm{O}_{2} 24 \mathrm{~h} ;{ }^{*} \mathrm{P}<0.05$ vs. $21 \% \mathrm{O}_{2} 48 \mathrm{~h}$; ${ }^{*} \mathrm{P}<0.05$ vs. $21 \% \mathrm{O}_{2} 72 \mathrm{~h}$. HIF-1 $\alpha$, hypoxia-inducible factor $1 \alpha$; TET2, Tet methylcytosine dioxygenase 2 .
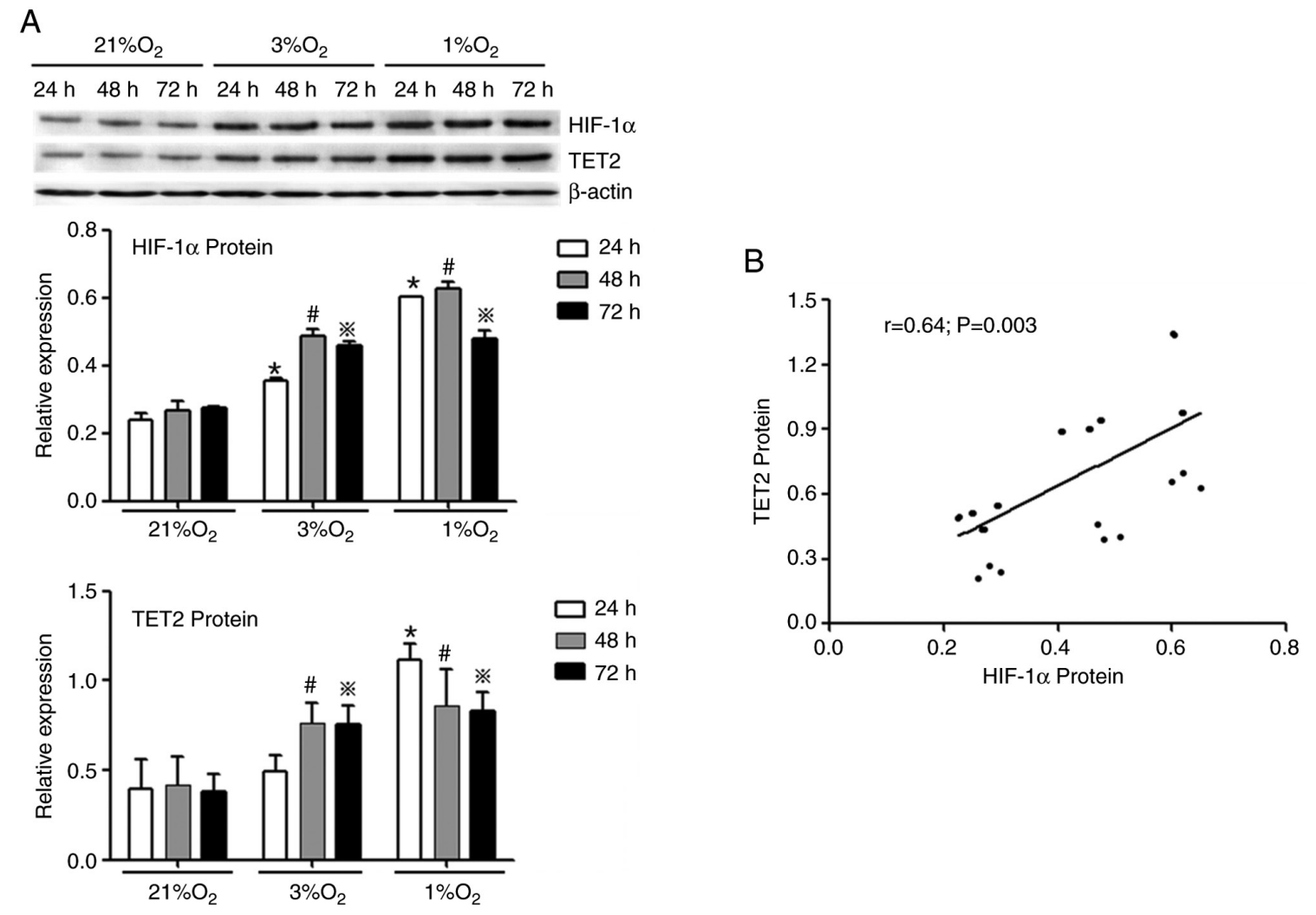

Figure 4. Effects of hypoxia on the expression (A) of HIF-1 $\alpha$ and TET2 protein in KG-1 cells and (B) the association between the expression of HIF-1 $\alpha$ and TET2. ${ }^{*} \mathrm{P}<0.05$ vs. $21 \% \mathrm{O}_{2} 24 \mathrm{~h} ;{ }^{*} \mathrm{P}<0.05$ vs. $21 \% \mathrm{O}_{2} 48 \mathrm{~h} ;{ }^{*} \mathrm{P}<0.05$ vs. $21 \% \mathrm{O}_{2} 72 \mathrm{~h}$. HIF-1 $\alpha$, hypoxia-inducible factor $1 \alpha$; TET2, Tet methylcytosine dioxygenase 2.

5-hmC in the GV358-HIF-1 $\alpha+$ hypoxia group was significantly higher compared with the GV358-HIF-1 $\alpha+$ normoxia group (Fig. 6C). Compared with the GV358 + hypoxia group, the 5-hmC content in the GV358-HIF-1 $\alpha+$ hypoxia group was 
A

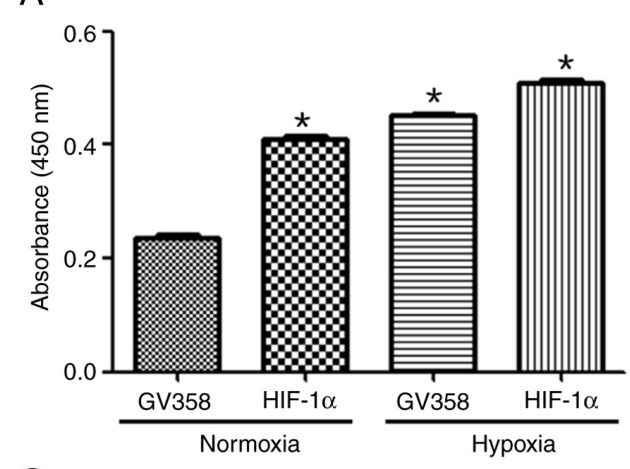

C

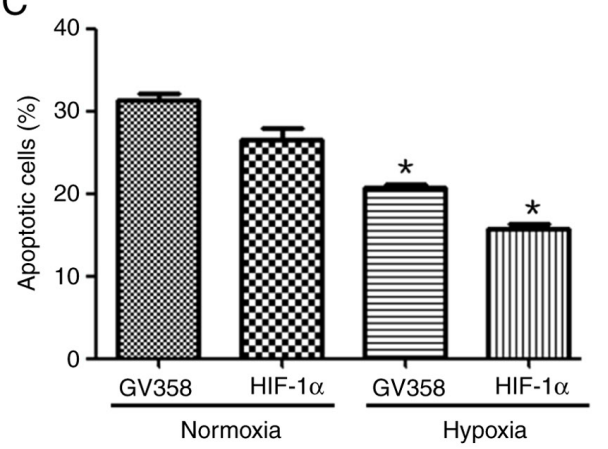

B

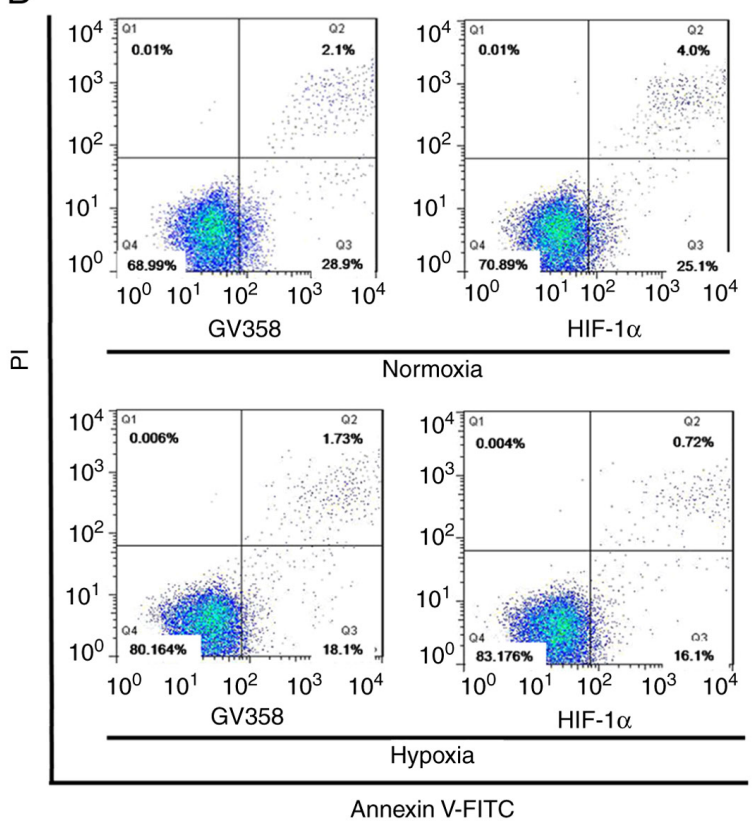

Figure 5. Effects of HIF-1 $\alpha$ overexpression on the proliferative activity detected by (A) Cell Counting Kit- 8 assay and (B and C) apoptosis by Annexin V-FITC/PI assay in KG-1 cells. * $\mathrm{P}<0.05$ vs. GV358 + normoxia group. HIF-1 $\alpha$, hypoxia-inducible factor $1 \alpha$; PI, propidium iodide.

A
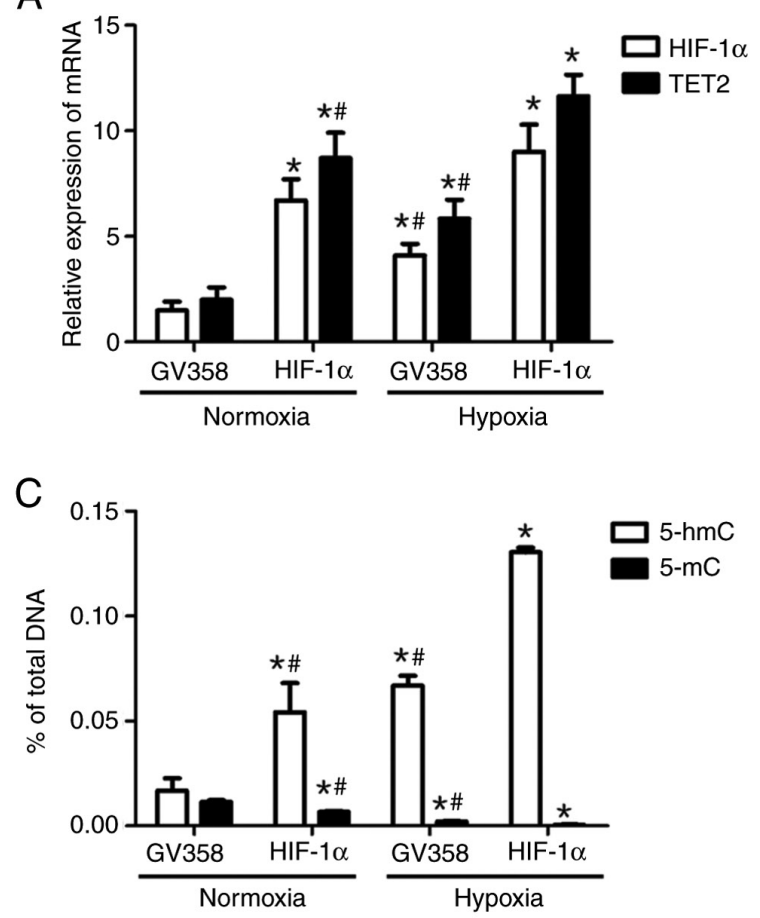

B

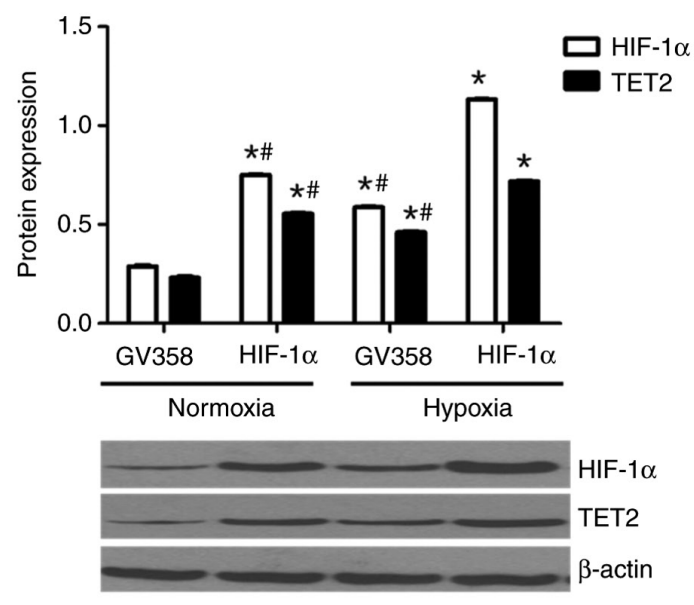

D

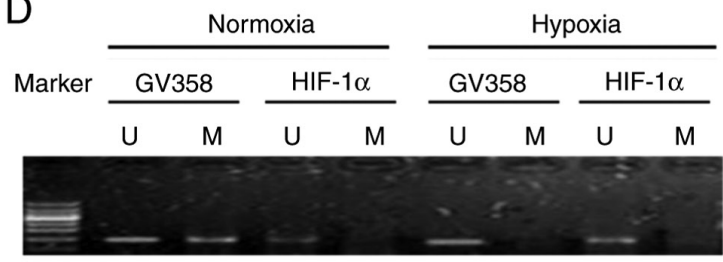

Figure 6. Effects of HIF-1 $\alpha$ overexpression on gene methylation status in KG-1 cells. (A) mRNA, (B) protein and (C) genome level of 5-hmC and 5-mC. ${ }^{*} \mathrm{P}<0.05$ vs. GV358 + normoxia group; ${ }^{\text {P }} \mathrm{P}<0.05$ vs. GV358-HIF-1 $\alpha+$ hypoxia group. (D) Methylation of the p15(INK4B) gene promoter region by MSP assay. M, PCR product amplified by methylated-specific primers; U, PCR product amplified by unmethylated-specific primers. HIF-1 $\alpha$, hypoxia-inducible factor 1 $\alpha$; 5-hmC, 5-hydroxymethylcytosine; 5-mC, 5-methylcytosine; MSP, methylation-specific PCR; TET2, Tet methylcytosine dioxygenase 2; p15(INK4B), cyclin-dependent kinase inhibitor $2 \mathrm{~B}$.

also increased (Fig. 6C). This indicated that the overexpression of HIF-1 $\alpha$ promoted the demethylation of KG-1 cells under both normoxic and hypoxic conditions (Fig. 6C).
Compared with the GV358 + normoxia group, the 5-mC content was decreased in the GV358-HIF- $1 \alpha+$ normoxia group (Fig. 6C). The 5-mC content in the GV358-HIF-1 $\alpha+$ hypoxia 

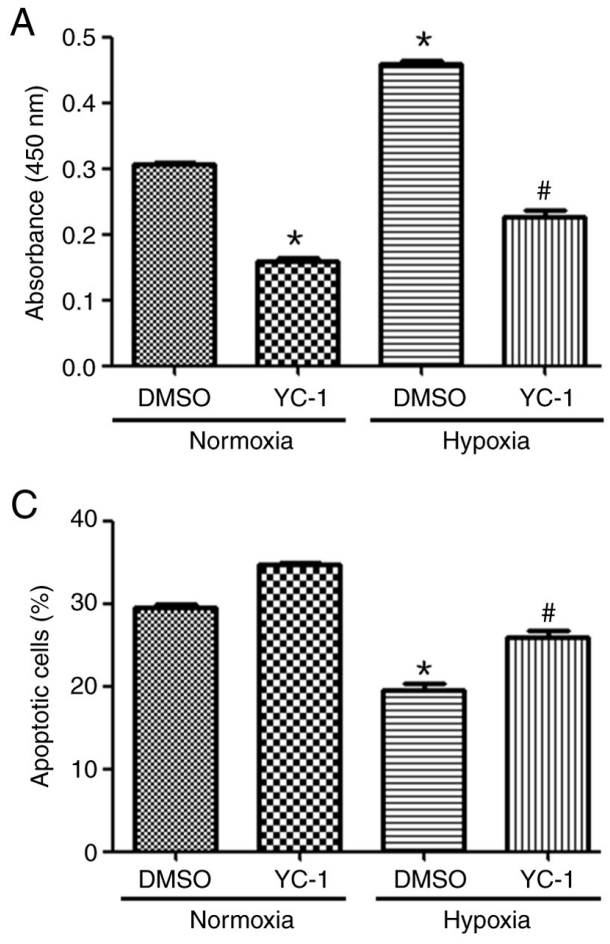

B

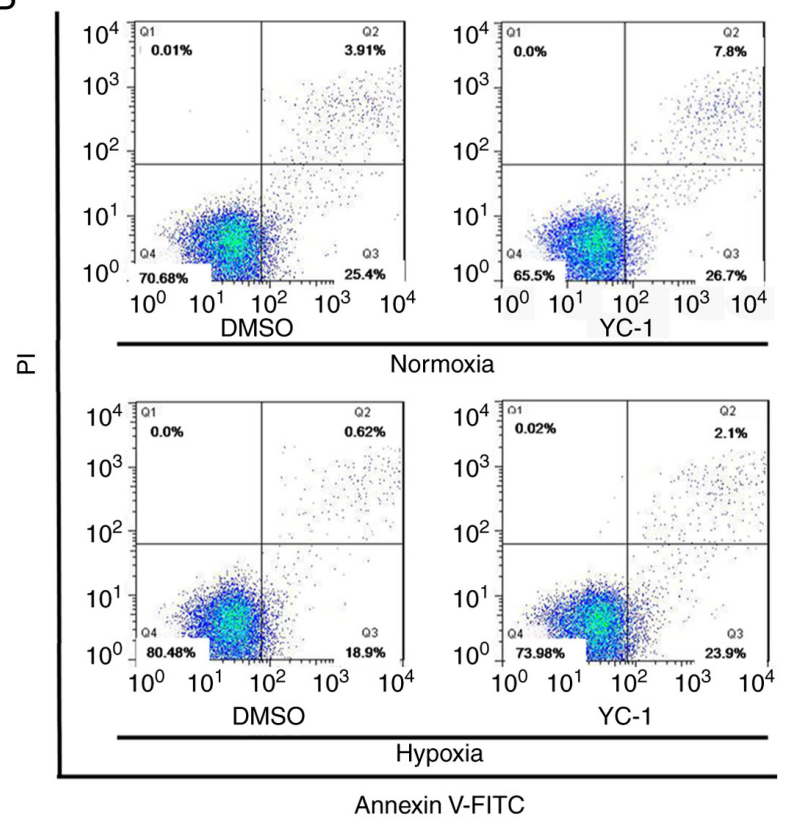

Figure 7. Effects of HIF-1 $\alpha$ suppression by YC-1 on the proliferative activity detected by (A) Cell Counting Kit- 8 assay and (B and C) apoptosis by Annexin V-FITC/PI assay in KG-1 cells. ${ }^{*} \mathrm{P}<0.05$ vs. DMSO + normoxia group; ${ }^{*} \mathrm{P}<0.05$ vs. DMSO + hypoxia. HIF-1 $\alpha$, hypoxia-inducible factor $1 \alpha$; PI, propidium iodide; YC-1, 3-(5'-hydroxymethyl-2'-furyl)-1-benzylindazole.

group was lower compared with that of the GV358-HIF-1 $\alpha+$ normoxia group (Fig. 6C). Compared with the GV358 + hypoxia group, 5-mC content was also decreased in the GV358-HIF-1 $\alpha$ + hypoxia group (Fig. 6C).

The p15(INK4B) promoter region of KG-1 cells demonstrated partial methylation under normoxia and it was demethylated after hypoxia or/and HIF-1 $\alpha$ overexpression (Fig. 6D). In summary, the overexpression of HIF-1 $\alpha$ promoted the demethylation of KG-1 cells by increasing TET2 expression.

HIF-1 $\alpha$ suppression decreases TET2 expression, 5-hmC level and p15(INK4B) gene demethylation in KG-1 cells. HIF-1 $\alpha$ inhibitor YC-1 (final concentration, $10 \mu \mathrm{mol} / 1$; $24 \mathrm{~h}$ ) was added to the cells to inhibit the expression of HIF-1 $\alpha$. The cells were divided into 4 groups: DMSO + normoxia, YC-1 + normoxia, DMSO + hypoxia and YC-1 + hypoxia. Compared with the DMSO+ normoxia group, the proliferation of YC-1 + normoxia group cells was decreased (Fig. 7A). Compared with the DMSO + hypoxia group, the cell proliferation in the YC-1+ hypoxia group was also decreased (Fig. 7A). The apoptotic rate of KG-1 cells was increased in HIF-1 $\alpha$ inhibited expressing cells and/or normoxic conditions compared with non-HIF-1 $\alpha$-inhibited expressing cells (Fig. 7B and C).

Compared with the DMSO + normoxia group, TET2 expression was decreased in $\mathrm{KG}-1$ cells from the YC-1 + normoxia group (Fig. 8A and B). Compared with the DMSO + hypoxia group, TET2 expression in the $\mathrm{YC}-1+$ hypoxia group was decreased (Fig. 8A and B). Meanwhile, the HIF-1 $\alpha$ mRNA and protein levels were downregulated in HIF-1 $\alpha$ expression inhibited cells under both normoxia and hypoxic conditions
(Fig. 8A and B). This indicated that the inhibition of HIF-1 $\alpha$ expression inhibited the expression of the TET2 mRNA and protein in $\mathrm{KG}-1$ cells under both normoxic and hypoxic conditions (Fig. 8A and B).

Compared with the DMSO + hypoxia group, the 5-hmC content of the KG-1 cell genome in the YC-1+ hypoxia group was decreased (Fig. 8C). This indicated that the inhibition of HIF-1 $\alpha$ expression could reduce the demethylation of KG-1 cells under hypoxic conditions. Compared with the $\mathrm{DMSO}+$ normoxia group, the 5-mC content of the genome of YC-1 + normoxia group cells was increased (Fig. 8C). Compared with the DMSO + hypoxia group, the 5-mC content of the genome was increased in $\mathrm{YC}-1$ + hypoxia group $\mathrm{KG}-1$ cells (Fig. 8C).

KG-1 cells showed partial methylation of the promoter region of the p15(INK4B) gene under normoxic conditions, which was demethylated under hypoxic conditions (Fig. 8D). p15(INK4B) gene promoter methylation was enhanced when HIF-1 $\alpha$ was inhibited by YC-1 (Fig. 8D). Overall, the inhibition of HIF-1 $\alpha$ reduced the demethylation of $\mathrm{KG}-1$ cells by decreasing TET2 expression.

HIF-1a promotes the transcriptional activity of the TET2 gene by binding to its promoter region. It was shown by ChIP that HIF-1 $\alpha$ bound to the $-1,133-1,022$ bp HRE site of the TET2 gene promoter in KG-1 cells under normoxic or hypoxic conditions (Fig. 9). The transcriptional activity of the promoter region of the TET2 gene in HIF-1 $\alpha$ overexpressing cells was significantly higher compared with that in all other groups (Fig. 10A), suggesting that the overexpression of HIF-1 $\alpha$ significantly enhanced the transcriptional activity of the TET2 promoter region in KG-1 cells. 

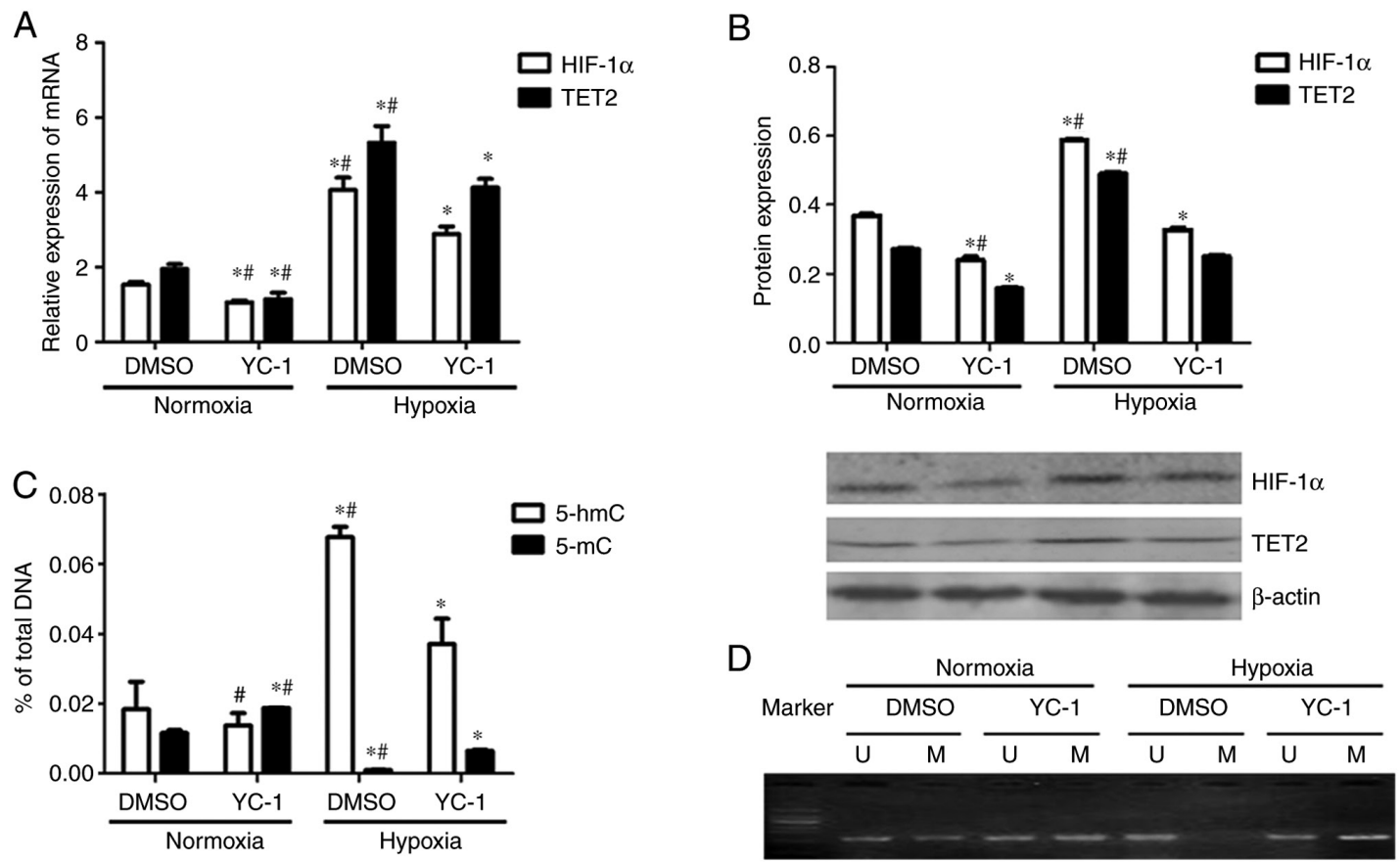

Figure 8. Effects of HIF-1 $\alpha$ suppression by YC-1 on gene methylation status in KG-1 cells. (A) mRNA, (B) protein and (C) genome level of 5-hmC and 5-mC. ${ }^{*} \mathrm{P}<0.05$ vs. DMSO + normoxia group; ${ }^{\mathrm{P}}<0.05$ vs. YC $-1+$ hypoxia. (D) Methylation of the p15(INK4B) gene promoter region by MSP assay. M, PCR product amplified by methylated-specific primers; U, PCR product amplified by unmethylated-specific primers. HIF-1 $\alpha$, hypoxia-inducible factor $1 \alpha ; 5$-mC, 5 -methylcytosine; 5-hmC, 5-hydroxymethylcytosine; YC-1, 3-(5'-hydroxymethyl-2'-furyl)-1-benzylindazole; MSP, methylation-specific PCR; TET2, Tet methylcytosine dioxygenase 2 .

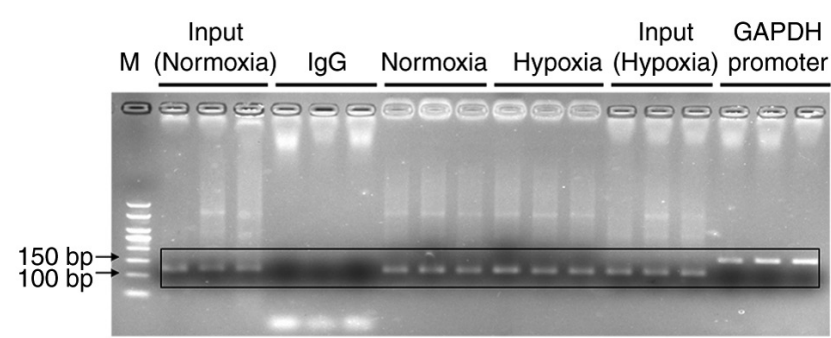

Figure 9 . HIF-1 $\alpha$ bound to the $-1,133-1,022$ bp of the TET2 gene promoter. Target band of each lane in the box. M, molecular marker; input, sample contains the total DNA after shearing with sonication; IgG, negative control using non-specific IgG as the antibody; GAPDH promoter, positive control expanded using primers designed of GAPDH core promoter region. HIF-1 $\alpha$, hypoxia-inducible factor $1 \alpha$; TET2, Tet methylcytosine dioxygenase 2 ; bp, base pair.

In addition, different doses of GV219-HIF-1 $\alpha$ eukaryotic expression $(0,1,2$ and $4 \mu \mathrm{g})$ and TET2 promoter luciferase reporter vectors were co-transfected into KG-1 cells and the relative luciferase activity was detected. It was shown that the higher the amount of the co-transfected GV219-HIF-1 $\alpha$ eukaryotic expression vector, the higher the transcriptional activity of the TET2 gene promoter (Fig. 10B), with a positive correlation identified (Fig. 10C). These results indicated that the overexpression of HIF-1 $\alpha$ promoted the transcriptional activity of the TET2 gene in a dose-dependent manner.

\section{Discussion}

A hypoxic environment has become an essential condition for maintaining hematopoietic stem cell homeostasis (31).
However, the effects and mechanism of hypoxia on hematologic malignancy cells are not fully understood (32). The hypoxic model can be induced by physical and chemical hypoxia (33). Chemical hypoxia agents, such as cobalt chloride and deferoxamine, can inhibit the prolyl hydroxylase domain(PHD) activity by PHD ligand $\mathrm{Fe}^{2+}$ substitution or chelation and then stablize the HIF-1 $\alpha$ protein $(33,34)$. However, due to the fact that the TET2 protease activity is also $\mathrm{Fe}^{2+}$-dependent, physical hypoxia was selected for the hypoxia model in the present study. The present study demonstrated that hypoxia promoted the proliferation and destruction, and inhibited the apoptosis of the KG-1 AML cell line. The increase of LDH activity in the cell culture medium in the present study suggested that cells underwent increased destruction under hypoxic conditions, which was not inconsistent with the increased proliferation activity of KG-1 cells in a hypoxic environment. Fu et al (35) found that because of the improvement of the high lactic acid environment at a later stage of cell culture, $\mathrm{CHO}$ cells with human LDH-C gene overexpression exhibited faster cell proliferation and stronger antiapoptotic ability compared with LDH-C gene non-overexpressed cells. In the present study, the effects of different levels and duration of hypoxia on cell proliferation were firstly observed. According to the proliferation and apoptosis results, the optimal hypoxic condition was selected, as ' $1 \% \mathrm{O}_{2}$ for $48 \mathrm{~h}$ '. This hypoxic condition was chosen in the present study for subsequent experimentation of effects of HIF- $1 \alpha$ overexpression and expression inhibition on TET2 expression and function. The findings of the present study suggested that cell metabolism was accelerated under hypoxic conditions and that hypoxia may serve certain roles, such as promoting proliferation and inducing apoptosis in the pathogenesis of AML. 
A

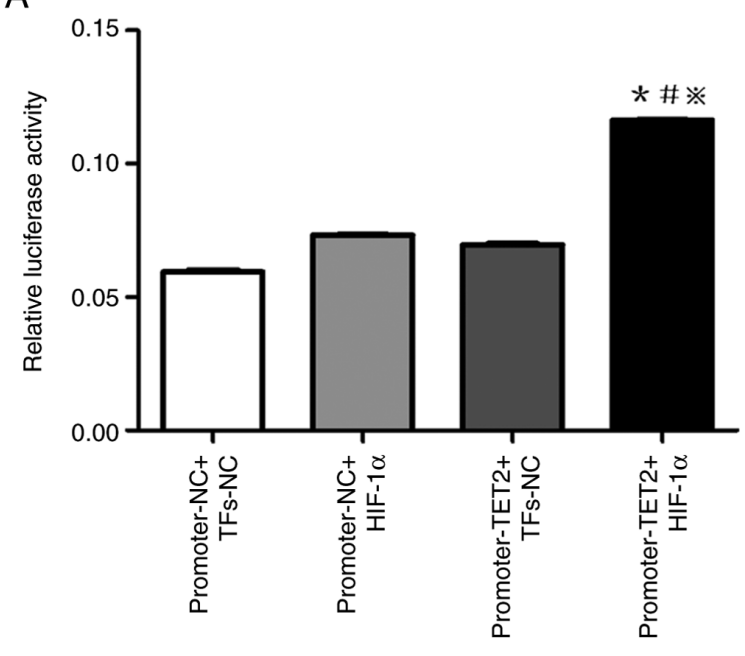

B
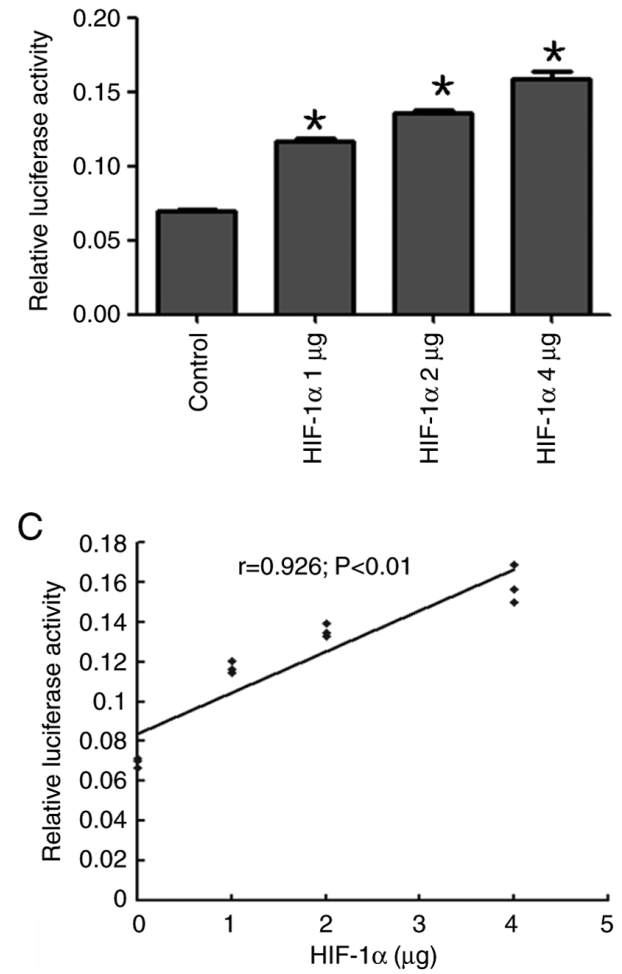

Figure 10. Effects of HIF-1 $\alpha$ on TET2 transcriptional activity, as detected by dual luciferase reporter gene assays. (A) TET2 gene transcriptional activity (Promoter-NC,GV354luciferase reporterempty vector;TFs-NC,GV219 overexpressionempty vector; promoter-TET2, GV354-TET2 promoterluciferase reporter vector; HIF-1 $\alpha$, GV219-HIF-1 $\alpha$ overexpression vector; NC, negative control). "P $<0.05$ vs. Promoter-NC + TFs-NC group; "P<0.05 vs. Promoter-NC+HIF-1a group; ${ }^{*} \mathrm{P}<0.05$ vs. Promoter-TET2 + TFs-NC group. (B) Effects of different doses of HIF-1 $\alpha$ eukaryotic expression plasmid on the transcriptional activity of TET2 promoter (Control, GV219 empty vector). "P<0.05 vs. empty vector group. (C) Correlation analysis of HIF-1 $\alpha$ eukaryotic expression plasmid doses and TET2 gene transcriptional activity. HIF-1 $\alpha$, hypoxia-inducible factor $1 \alpha$; TET2, Tet methylcytosine dioxygenase 2.

As an important tumor suppressor gene related to epigenetic modification, the mechanism of TET2 gene regulation remains unclear (36). At the pre-mRNA level, multiple studies have confirmed that microRNAs [miR-22, miR-29, miR-101 and miR-125] negatively regulate TET2 expression $(37,38)$. At the transcriptional level, the transcription factor Oct4 positively regulates the expression of TET2 in mouse embryonic stem cells by binding to the conserved domains of TET2 (39). At the posttranslational level, the inhibition of the dvl and axin complex (IDAX) protein binds directly to the unmethylated $\mathrm{CpG}$ dinucleotide of the promoter region/ $\mathrm{CpG}$ island of TET2, but then IDAX activates the caspase leading to the TET2 protein degradation (40). Other studies have found that vitamin $\mathrm{C}$ can restore and enhance TET2 enzymatic activity to suppress leukemia $(41,42)$. The present study found that hypoxia promoted the transcriptional expression of the TET2 gene through the transcription factor HIF-1 $\alpha$, which binds to the HRE of the promoter region of the TET2 gene, thus affecting the methylation status and expression of downstream target genes.

In recent years, the link between cellular hypoxia metabolism and epigenetic regulation has become a new signaling pathway (43). Certain products in the process of cellular hypoxia metabolism can affect the opening or closing of specific cell-cycle arrest, DNA repair and apoptosis genes, such as p15(INK4B) and Bcl-2 through epigenetic effects $(44,45)$. Normal and cancer cells have different metabolites which are used for epigenetic modification (46). Therefore, it is important to understand which metabolites can regulate gene function and whether they regulate gene function through epigenetic means or a combination with transcription factors or other processes, such as autophagy (47). Methionine metabolism is essential for Sirtuin 1 (SIRT1)-regulated mouse embryonic stem cell maintenance and embryonic development, when SIRT1 is knocked out in mouse embryonic stem cells, the methionine content is increased and numerous histone methylation markers, such as (MAT2a) are lost (48). By constructing a T cell line deficient in LDHA (a key enzyme for aerobic glycolysis) (49), Brand et al (49) found that the histone acetylation and gene expression patterns in wild-type and LDHA-knockout cells are different. Galligan et al (50) described the existence of Lys and Arg modifications on histones derived from a glycolytic by-product, methylglyoxal. These histone posttranslational modifications were shown to be present during the modulation of chromatin function and lead to altered gene transcription, which provided a link between cellular metabolism and the histone code (50).

The abnormal methylation of the p15(INK4B) gene is more common in the occurrence and development of hematologic malignancies (51). Hence, the tumor suppressor gene p15(INK4B) was selected in the present study to analyze its methylation status. In the present study, methylation of the promoter region of the p15(INK4B) gene in KG-1 cells was detected by the MSP method. Among numerous methylation detection methods, Methylation-Specific PCR (MSP) is likely the most widely used technique to study DNA methylation of 
a locus of interest (52). However, as the degree of methylation cannot be quantified, its application is limited (53). In the present study it was found that under normoxia, the promoter region of the p15(INK4B) gene was partially methylated and following hypoxia or HIF-1 $\alpha$ overexpression, the promoter region of the p15(INK4B) gene was demethylated, indicating that the demethylation of this gene was regulated by HIF-1 $\alpha$. In the present study, the increased methylation of the p15(INK4B) gene following HIF-1 $\alpha$ inhibition further confirmed this. p15(INK4B) is considered a target gene of HIF-1 $\alpha$ (54), but the specific mechanism through which $\mathrm{HIF}-1 \alpha$ regulates p15(INK4B) gene methylation is not clear. Kroeze et al (55) found that most of the 206 patients with AML with low 5-hmC exhibited an increased methylation status of the p15(INK4B) promoter, which was consistent with the results of the present study. Shimamoto et al (56) found that the methylation rate of the p15(INK4B) gene in AML reached 51\%, which was contrary to the results of the present study. This difference may be associated with AML subtypes, detection methods and examined sites. Methylation is a dynamic and reversible process (57). In the present study, HIF-1 $\alpha$ overexpression caused genome and p15(INK4B) gene demethylation in KG-1 cells, resulting in the loss of p15(INK4B) gene function and the malignant proliferation of leukemic cells. However, the association between the abnormal methylation mechanism of the p15(INK4B) gene and leukemia requires further study.

The present study investigated the genomic methylation and change of methylation status in the representative gene p15(INK4B) during AML cell hypoxia metabolism, as well as the effect of hypoxia metabolism on the expression of demethylase TET2. The results of the present study, revealed that hypoxia regulated the transcriptional expression of TET2 through HIF-1 $\alpha$ which, in turn, affected the methylation status and expression of genes, such as p15(INK4B) in leukemic cells.

The human acute myeloid leukemia KG-1 cell line was chosen as the main research object representatively in this study and other cell lines such as K562, HL-60 and U937 will been chosen in the follow-up experiments. Different types of leukemia cells have different tolerance to hypoxia and the mechanism needs to be further studied. Although much work is still required to fully understand the role of hypoxia metabolism in leukemia, the present study shed light on a link between hypoxia metabolism and DNA demethylation. The development of HIF-1 $\alpha$-specific targeted drugs should be the focus of further studies.

In conclusion, molecular targeted therapy is currently used for the treatment of acute leukemia, with an increasing number of drugs, such as hypomethylating agents, isocitrate dehydrogenase and $\mathrm{Bcl}-2$ inhibitors being used in the clinic. The results of the present study indicated that TET2 is an attractive target gene of HIF-1 $\alpha$ transcriptional regulation in AML cells.

\section{Acknowledgements}

Not applicable.

\section{Funding}

The present study was supported by the National Natural Science Foundation of China (grant no. 81500141).

\section{Availability of data and materials}

The datasets used and/or analyzed during the current study are available from the corresponding author upon reasonable request.

\section{Authors' contributions}

PH, JL and XLL conceived and designed the present study. PH, JL, LXZ, GZZ, LP, and QD performed the experiments and analyzed the data. PH drafted the initial manuscript. JL and LXZ revised the manuscript. PH and XLL confirmed the authenticity of all the raw data. All authors have read and approved the final manuscript.

\section{Ethics approval and consent to participate}

Not applicable.

\section{Patient consent for publication}

Not applicable.

\section{Competing interests}

The authors declare that they have no competing interests.

\section{References}

1. Estey EH: Acute myeloid leukemia: 2019 update on risk-stratification and management. Am J Hematol 93: 1267-1291, 2018.

2. Brahimi-Horn MC, Chiche J and Pouysségur J: Hypoxia and cancer. J Mol Med (Berl) 85: 1301-1307, 2007.

3. Parmar K, Mauch P, Vergilio JA, Sackstein R and Down JD: Distribution of hematopoietic stem cells in the bone marrow according to regional hypoxia. Proc Natl Acad Sci USA 104: 5431-5436, 2007.

4. Kubota Y, Takubo $\mathrm{K}$ and Suda T: Bone marrow long label-retaining cells reside in the sinusoidal hypoxic niche. Biochem Biophys Res Commun 366: 335-339, 2008.

5. Schepers K, Campbell TB and Passegué E: Normal and leukemic stem cell niches: Insights and therapeutic opportunities. Cell Stem Cell 16: 254-267, 2015.

6. Tabe $\mathrm{Y}$ and Konopleva M: Advances in understanding the leukaemia microenvironment. Br J Haematol 164: 767-778, 2014.

7. Webb JD, Coleman ML and Pugh CW: Hypoxia, hypoxia-inducible factors (HIF), HIF hydroxylases and oxygen sensing. Cell Mol Life Sci 66: 3539-3554, 2009.

8. Semenza GL: Targeting HIF-1 for cancer therapy. Nat Rev Cancer 3: 721-732, 2003.

9. Wellmann S, Guschmann M, Griethe W, Eckert C, von Stackelberg A, Lottaz C, Moderegger E, Einsiedel HG, Eckardt KU, Henze G and Seeger K: Activation of HIF pathway in childhood ALL, prognostic implications of VEGF. Leukemia 18: 926-933, 2004.

10. Deeb G, Vaughan MM, McInnis I, Ford LA, Sait SN, Starostik P, Wetzler M, Mashtare T and Wang ES: Hypoxia-inducible factor-1 $\alpha$ protein expression is associated with poor survival in normal karyotype adult acute myeloid leukemia. Leuk Res 35: 579-584, 2011.

11. Song LP, Zhang J, Wu SF, Huang Y, Zhao Q, Cao JP, Wu YL, Wang LS and Chen GQ: Hypoxia-inducible factor-1alpha-induced differentiation of myeloid leukemic cells is its transcriptional activity independent. Oncogene 27: 519-527, 2008.

12. Melki JR, Vincent PC and Clark SJ: Concurrent DNA hypermethylation of multiple genes in acute myeloid leukemia. Cancer Res 59: 3730-3740, 1999.

13. Liu Q, Liu L, Zhao Y, Zhang J, Wang D, Chen J, He Y, Wu J, Zhang $\mathrm{Z}$ and Liu Z: Hypoxia induces genomic DNA demethylation through the activation of HIF-1 $\alpha$ and transcriptional upregulation of MAT2A in hepatoma cells. Mol Cancer Ther 10: 1113-1123, 2011. 
14. Bristow RG and Hill RP: Hypoxia and metabolism: Hypoxia, DNA repair and genetic instability. Nat Rev Cancer 8: 180-192, 2008.

15. McCarty G and Loeb DM: Hypoxia-sensitive epigenetic regulation of an antisense-oriented lncRNA controls WT1 expression in myeloid leukemia cells. PLoS One 10: e0119837, 2015.

16. Tahiliani M, Koh KP, Shen Y,Pastor WA, Bandukwala H, Brudno Y, Agarwal S, Iyer LM, Liu DR, Aravind L and Rao A: Conversion of 5-methylcytosine to 5-hydroxymethylcytosine in mammalian DNA by MLL partner TET1. Science 324: 930-935, 2009.

17. Li W and Liu M: Distribution of 5-hydroxymethylcytosine in different human tissues. J Nucleic Acids 2011: 870726, 2011.

18. Nikoloski G, Langemeijer SM, Kuiper RP, Knops R, Massop M, Tönnissen ER, van der Heijden A, Scheele TN, Vandenberghe P, de Witte T, et al: Somatic mutations of the histone methyltransferase gene EZH 2 in myelodysplastic syndromes. Nat Genet 42 : 665-667, 2010

19. Delhommeau F, Dupont S, Della Valle V, James C, Trannoy S, Massé A, Kosmider O, Le Couedic JP, Robert F, Alberdi A, et al: Mutation in TET2 in myeloid cancers. N Engl J Med 360: 2289-2301, 2009.

20. Xu YP, Lv L, Liu Y, Smith MD, Li WC, Tan XM, Cheng M, Li Z, Bovino M, Aubé J and Xiong Y: Tumor suppressor TET2 promotes cancer immunity and immunotherapy efficacy. J Clin Invest 129: 4316-4331, 2019.

21. Schumann U, Lee J, Kazan K, Ayliffe M and Wang MB: DNA-Demethylase regulated genes show methylation-independent spatiotemporal expression patterns. Front Plant Sci 8: 1449, 2017.

22. Nobori T, Miura K, Wu DJ, Lois A, Takabayashi K and Carson DA: Deletions of the cyclin-dependent kinase-4 inhibitor gene in multiple human cancers. Nature 368: 753-756, 1994.

23. Hannon GJ and Beach D: p15INK4B is a potential effector of TGF-beta-induced cell cycle arrest. Nature 371: 257-261, 1994.

24. Herman JG, Jen J, Merlo A and Baylin SB: Hypermethylation-associated inactivation indicates a tumor suppressor role for p15INK4B. Cancer Res 56: 722-727, 1996.

25. Tien HF, Tang JH, Tsay W, Liu MC, Lee FY, Wang CH, Chen YC and Shen MC: Methylation of the p15(INK4B) gene in myelodysplastic syndrome: It can be detected early at diagnosis or during disease progression and is highly associated with leukaemic transformation. Br J Haematol 112: 148-154, 2001.

26. Wang J, He N, Wang R, Tian T, Han F, Zhong C, Zhang C, Hua M, Ji C and Ma D: Analysis of TET2 and EZH2 gene functions in chromosome instability in acute myeloid leukemia. Sci Rep 10: 2706,2020

27. Livak KJ and Schmittgen TD: Analysis of relative gene expression data using real-time quantitative PCR and the 2(-Delta Delta C(T)) method. Methods 25: 402-408, 2001

28. Yeo EJ, Chun YS and Park JW: New anticancer strategies targeting HIF-1. Biochem Pharmacol 68: 1061-1069, 2004.

29. Herman JG, Graff JR, Myohanen S, Nelkin BD and Baylin SB Methylation-specific PCR: A novel PCR assay for methylation status of CpG islands. Proc Natl Acad Sci USA 93: 9821-9826, 1996.

30. Lan F, Bayliss PE, Rinn JL, Whetstine JR, Wang JK, Chen S, Iwase S, Alpatov R, Issaeva I, Canaani E, et al: A histone H3 lysine 27 demethylase regulates animal posterior development. Nature 449: 689-694, 2007

31. Deynoux M, Sunter N, Hérault O and Mazurier F: Hypoxia and hypoxia-inducible factors in leukemias. Front Oncol 6: 41, 2016.

32. Cui XY, Skretting G, Jing Y, Sun H, Sandset PM and Sun L: Hypoxia influences stem cell-like properties in multidrug resistant K562 leukemic cells. Blood Cells Mol Dis 51: 177-184, 2013

33. Piret JP, Mottet D, Raes $\mathrm{M}$ and Michiels C: $\mathrm{CoCl}_{2}$, a chemical inducer of hypoxia-inducible factor-1, and hypoxia reduce apoptotic cell death in hepatoma cell line HepG2. Ann NY Acad Sci 973: 443-447, 2002.

34. Lee JW, Bae SH, Jeong JW, Kim SH and Kim KW: Hypoxia-inducible factor (HIF-1) alpha: Its protein stability and biological functions. Exp Mol Med 36: 1-12, 2004

35. Fu T, Zhang C, Jing Y, Jiang C, Li Z, Wang S, Ma K, Zhang D, Hou S, Dai J, et al: Regulation of cell growth and apoptosis through lactate dehydrogenase $\mathrm{C}$ over-expression in Chinese hamster ovary cells. Appl Microbiol Biotechnol 100: 5007-5016, 2016.

36. Pasca S, Jurj A, Zdrenghea $M$ and Tomuleasa C: The potential equivalents of TET2 mutations. Cancers (Basel) 13: 1499, 2021.

37. Song SJ, Ito K, Ala U, Kats L, Webster K, Sun SM, JongenLavrencic M, Manova-Todorova K, Teruya-Feldstein J, Avigan DE, et al: The oncogenic microRNA miR-22 targets the TET2 tumor suppressor to promote hematopoietic stem cell self-renewal and transformation. Cell Stem Cell 13: 87-101, 2013
38. Cheng J, Guo S, Chen S, Mastriano SJ, Liu C, D'Alessio AC, Hysolli E, Guo Y, Yao H, Megyola CM, et al: An extensive network of TET2-targeting MicroRNAs regulates malignant hematopoiesis. Cell Rep 5: 471-481, 2013.

39. Koh KP, Yabuuchi A, Rao S, Huang Y, Cunniff K, Nardone J, Laiho A, Tahiliani M, Sommer CA, Mostoslavsky G, et al: Tet1 and Tet2 regulate 5-hydroxymethylcytosine production and cell lineage specification in mouse embryonic stem cells. Cell Stem Cell 8: 200-213, 2011.

40. Ko M, An J, Bandukwala HS, Chavez L, Aijö T, Pastor WA, Segal MF, Li H, Koh KP, Lähdesmäki H, et al: Modulation of TET2 expression and 5-methylcytosine oxidation by the CXXC domain protein IDAX. Nature 497: 122-126, 2013

41. Cimmino L, Dolgalev I, Wang Y, Yoshimi A, Martin GH, Wang J, Ng V, Xia B, Witkowski MT, Mitchell-Flack M, et al: Restoration of TET2 function blocks aberrant self-renewal and leukemia progression. Cell 170: 1079-1095.e20, 2017.

42. Harjes U: Leukaemia: Beyond the C. Nat Rev Cancer 17: 573 , 2017.

43. Thienpont B, Steinbacher J, Zhao H, D'Anna F, Kuchnio A, Ploumakis A, Ghesquière B, Van Dyck L, Boeckx B, Schoonjans L, et al: Tumor hypoxia causes DNA hypermethylation by reducing TET activity. Nature 537: 63-68, 2016.

44. Choudhry $\mathrm{H}$ and Harris AL: Advances in hypoxia-inducible factor biology. Cell Metab 27: 281-298, 2018.

45. Lin YT and Wu KJ: Epigenetic regulation of epithelial-mesenchymal transition: Focusing on hypoxia and TGF- $\beta$ signaling. J Biomed Sci 27: 39, 2020.

46. Mikirova NA: Bioenergetics of human cancer cells and normalcells during proliferation and differentiation. Br J Med Med Res 7: 971-982, 2015.

47. Iaccarino I and Martins LM: Therapeutic targets in cancer cell metabolism and death. Cell Death Differ 18: 565-570, 2011

48. Tang S, Fang Y, Huang G, Xu X, Padilla-Banks E, Fan W, $\mathrm{Xu} \mathrm{Q}$, Sanderson SM, Foley JF, Dowdy S, et al: Methionine metabolism is essential for SIRT1-regulated mouse embryonic stem cell maintenance and embryonic development. EMBO J 36: 3175-3193, 2017.

49. Brand A, Singer K, Koehl GE, Kolitzus M, Schoenhammer G, Thiel A, Matos C, Bruss C, Klobuch S, Peter K, et al: LDHA-associated lactic acid production blunts tumor immunosurveillance by T and NK cells. Cell Metab 24: 657-671, 2016.

50. Galligan JJ, Wepy JA, Streeter MD, Kingsley PJ, Mitchener MM, Wauchope OR, Beavers WN, Rose KL, Wang T, Spiegel DA and Marnett LJ: Methylglyoxal-derived posttranslational arginine modifications are abundant histone marks. Proc Natl Acad Sci USA 115: 9228-9233, 2018.

51. Christiansen DH, Andersen MK and Pedersen-Bjergaard J: Methylation of p15INK4B is common, is associated with deletion of genes on chromosome arm $7 \mathrm{q}$ and predicts a poor prognosis in therapy-related myelodysplasia and acute myeloid leukemia. Leukemia 17: 1813-1819, 2003

52. Yokoi K, Yamashita K and Watanabe M: Analysis of DNA methylation status in bodily fluids for early detection of cancer. Int J Mol Sci 18: 735, 2017

53. Ramalho-Carvalho J, Henrique $\mathrm{R}$ and Jerónimo $\mathrm{C}$ : Methylation-Specific PCR. Methods Mol Biol 1708: 447-472, 2018.

54. Fujii T, Otsuki T, Moriya T, Sakaguchi H, Kurebayashi J, Yata K, Uno M, Kobayashi T, Kimura T, Jo Y, et al: Effect of hypoxia on human seminoma cells. Int J Oncol 20: 955-962, 2002.

55. Kroeze LI, Aslanyan MG, van Rooij A, Koorenhof-Scheele TN, Massop M, Carell T, Boezeman JB, Marie JP, Halkes CJ, de Witte T, et al: Characterization of acute myeloidleukemia based on levels of global hydroxymethylation. Blood 124: 1110-1118, 2014

56. Shimamoto T, Ohyashiki JH and Ohyashiki K: Methylation of p15(INK4b) and E-cadherin genes is independently correlated with poor prognosis in acute myeloid leukemia. Leuk Res 29: 653-659, 2005 .

57. Zhao L, Duan YT, Lu P, Zhang ZJ, Zheng XK, Wang JL and Feng WS: Epigenetic targets and their inhibitors in cancer therapy. Curr Top Med Chem 18: 2395-2419, 2018.

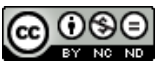

This work is licensed under a Creative Commons Attribution-NonCommercial-NoDerivatives 4.0 International (CC BY-NC-ND 4.0) License. 